\title{
Reforming Land Tenure Policies After Civil War: A Comparative Analysis of Rwanda \& Côte d'Ivoire
}

\author{
By Katherine M. Cronin
}

Using Côte d'Ivoire and Rwanda as case studies, this paper explores the challenges of implementing strong land tenure policies and promoting peace in post-conflict environments. This paper analyzes the degree to which a lack of clear time horizons, land boundaries, land transfer laws, and enforcement capacity to uphold land tenure laws increases the risk for land-related conflict to occur. Furthermore, this paper adds to the existing literature that supports the implementation and promotion of new and more equitable land tenure laws in post-conflict reconstruction processes in order to fix the deficiencies that contributed to the initial conflict.

\section{Introduction}

Land tenure, or property rights, refers to the body of rights that regulate the use, control, and distribution of land (Rassam 1990). In general, underlying codified land tenure policies are social, cultural, legal, and economic relationships that do not always reflect or follow the codified laws. Over recent decades, land tenure has been a source of conflict across the globe in places like Israel and Palestine, Serbia and Bosnia, Mexico, Guatemala, Somalia, Zimbabwe, Mauritania, and Brazil to name only a few. How land tenure policies can be best structured so as to lead to peace and economic growth has been the subject of a growing body of literature. In 2003, the World Bank released its 300-page report that summarized much of this literature and outlined best practices in land tenure policy. According to the report, in an ideal case, appropriate national and local governments work together to ensure that their institutions structure land tenure policies in such a way as to maximize investment in land and foster economic growth (World Bank 2003). In order for this to occur, clear laws regarding time horizons, land boundaries, and transfers, as well as the institutions with enforcement capability to uphold those laws, need to be in place (2003). If any of these elements are lacking, as they are in much of sub-Saharan Africa, risk increases for land-related conflict to occur.

In an effort to further explore the relationship between land tenure and conflict, this paper uses Côte d'Ivoire and Rwanda as case studies to explore the challenges of implementing strong land tenure policies in post-conflict environments. In addition, this paper seeks to add to the existing body of literature that supports the argument that the implementation of new, more equitable land tenure policies should be a priority in the post-conflict reconstruction process in order to fix the deficiencies that contributed to the initial conflict (Hendrix 1997). In order to achieve this, the actors involved in post-conflict resolution, including local and foreign governments, multilateral organizations, and NGOs, must develop a comprehensive understanding of the pre-conflict land tenure system and its core deficiencies. 
Drawing primarily from the summary conclusions outlined in the World Bank report, this article begins with a more robust discussion on best practices in land tenure policies, including a more in-depth discussion of the recommended requirements for successful land tenure. Next, it outlines the pre-conflict land tenure systems in both Rwanda and Côte d'Ivoire and describes how they contributed to the build up to their civil wars in 1990 and 2002 (note that this is the relative date of the start of the first Ivoirian Civil War, not the second which began in 2011), respectively. Moving on, it analyzes the post-conflict land tenure policies that each country has implemented to determine whether these new policies have adequately addressed the pre-conflict deficiencies and also whether these policies have incorporated any best practices. It concludes with a broader discussion, including policy recommendations, about the importance of strong land tenure policy in reconstituting legitimacy, establishing security, and rebuilding effectiveness in post-conflict environments.

\section{The Benefits of Secure Land Tenure}

As noted in the World Bank's report, successful land tenure policies are essential for economic growth, stability, development, and poverty reduction in sub-Saharan Africa. This is not surprising given that land is the primary unit of wealth across the region, and thus, the amount of land a family holds and level of security they have with respect to their holdings is of great importance, particularly in rural areas. Securing land tenure rights is the foundation for economic activity. Having secure rights to land increases incentives for households to invest in the land. Investments could include additional land clearing for crop production, the purchase of mechanical farm tools, or better inputs such as drought-resistant seeds, herbicides, and pesticides. Having secure rights to land also means that landowners will not be forced to spend their time and money entangled in land disputes, during which their land is less likely to be productive (World Bank 2003). Finally, landholders who feel their land rights are secure are also more likely to rent some portion of their land to others, which can generate additional income for the land owner, increase land productivity, and also generate employment opportunity for the landless poor in rural areas (IFAD 2012).

This last point dovetails with another key benefit of achieving stable and secure land tenure rights: poverty reduction. Landowners who continue to invest in their land and increase productivity are more likely to create employment opportunities for others, thus helping to reduce poverty. As their land becomes more productive, the need for additional labor increases. In addition, having secure land rights increases the likelihood of landowners accessing credit, which can be used to purchase additional inputs and can also act as a form of insurance during poor crop years (World Bank 2003).

Both the World Bank and the Food and Agriculture Organization of the United Nations (FAO) have outlined baseline requirements for successful land tenure systems (Derringer 2003; World Bank 2003). The first of these key characteristics is duration, or length of time during which a person's right to a designated parcel of land is guaranteed. Indefinite rights are ideal, but other long-term periods, such as 99-year leases or shorter terms with easily renewable options are also possible. Long time horizons are an essential component of a successful land tenure policy, as they provide incentives for people to invest in the land. The second important attribute of a successful land tenure policy is that boundaries of the land must be clear in order to avoid disputes between landowners. Again, this is important for economic growth, as any time spent engaged in land disputes is less time spent increasing the productivity of the land in question. Clear 
land transfer rules are the third element needed. Not only must the rules for land transfer, including inheritance, rent, gift, and sale of land be clear, but the cost of those transactions must be low so that the transactions can be executed quickly and efficiently. The fourth and final element to a successful land tenure policy is that the policy is administered and enforced by institutions that are accountable, legitimate, and legal. Underlying this fourth element is the assumption that there are enough trained civil servants available to administer and enforce the policy.

While these suggestions seem straightforward, implementing them can be a challenge in environments where the cultural concept of land tenure is different from the Western notion that private land ownership is preferable to communal or collective forms of tenure (Peters 2009). Implementation can be further compromised in regions where land scarcity is increasing, ownership opportunity is unequal, land issues are intertwined with ethnic issues, or where there are autochthonous versus immigrant tensions. Unfortunately, ineffective land tenure policies that exist in these environments can contribute to conflict. The FAO's 2005 paper on land tenure notes:
Access to land is often related to social identity, the rights to land of people may be used in the political exploitation of tension. Where owner- ship of land is concentrated in the hands of a minority, whether based on class or ethnicity, the demands for land reform may lead to a violent struggle. Tenure is- sues are essentially political, and tenure relationships are imbedded in, and affected by, class or ethnic relationships. Tenure issues are liable to become politicized, and political issues are liable to become ethnicized.

The World Bank also summarizes that "where long standing, systematic distortions in the area of land overlap with race and ethnicity issues, a buildup of landrelated conflict and violence can result in collapse of the state, with devastating consequences" (World Bank 2003, 21).

\section{Pre-Conflict Land Tenure Policies: Rwanda and Côte d'Ivoire}

In the years leading up to the civil wars in Rwanda and Côte d'Ivoire, land tenure policies in both countries lacked many of the elements needed for success. These deficiencies, coupled with the socio-economic and ethnic tensions in both countries, contributed to the downward spiral that erupted in civil wars. This paper does not argue that land tenure issues were the primary cause of either civil war, but rather that they contributed to it along with other factors. This section outlines in greater detail the pre-conflict land tenure policies in both countries and describes how they contributed to conflict.

\section{Rwanda}

Unequal access and distribution of land in Rwanda date back to the colonial period when the Belgian colonial administrators changed the land tenure regimes to favor the Tutsi ethnic group above the Hutu ethnic group. In the early 2oth century, land was lumped into two broad categories: land areas that were under the control of the central court and those that were not. The land areas controlled by the central court were under a tenure system called "isambu" in which all land belonged to the Tutsi king who then leased land in return for labor. Noncourt held land was allocated via lineage systems called "ubukonde." Under this system, people could request land from the male lineage head. Over time, as the colonial power assumed more control, more lands were converted from the ubukonde system to the isambu system, which the Belgians then codified (Crook 
2006). This codification changed the traditional lineage-based allocation of land rights as the Belgian-backed Tutsi court rejected the legitimacy of the ubukonde system. The additional labor requirement under the court system became an additional burden for the people given the already extractive nature of Belgian rule (Pottier 2002). This system further alienated the Hutus from the Tutsis and codified a significant legal difference between the two groups based solely on Belgian application of ethnicity.

Towards the end of the colonial period, Belgian preference for Tutsis shifted to favor Hutus. When the Belgians pulled out of Rwanda and the Tutsi monarchy collapsed, Rwanda came under the control of the Hutu PARMEHUTU party (Parti du Mouvement de l'Emancipation Hutu). During this period of "social revolution," many Tutsi landowners fled the country in what became known as the "first Tutsi exodus" (Huggins 2005). In 1962, the government established its first constitution, which continued the centralized land tenure policies first initiated by the Belgians. Under the laws, all land currently occupied was declared the property of the occupier. This meant that the land Tutsi owners were forced to leave behind in the social revolution was declared the property of those who were now occupying it. All lands previously held by the Belgian-supported, court-appointed Tutsi king were brought under state control and opened for cultivation. In addition, any land sales had to be cleared through the Ministry of Agriculture (Crook 2006).

Under these policies, the wealthy began to consolidate land (Musahara and Huggins 2005). By 1984, approximately half of the country's land was owned by only 15 percent of the population (Huggins 2005). While land was being consolidated in the hands of the few, population was also increasing-from approximately 6.6 million in 1988 to 8.8 million in 1998-resulting in rising population pressure and increased land scarcity (Aka 2007). This limited access to land, amplified by its unequal distribution, is cited as one of the key structural issues that contributed to the social tension that led to conflict (Huggins 2005). Unequal access was also one of the causes of poverty in the pre-war environment that was exploited by organizers of the 1994 genocide (2005).

Despite the codified laws and the increasing land consolidation, little was changing for the rural poor for whom informal land exchanges via bribes and labor remained the norm. The problem with the existence of these dual systems, formal and informal, was that there was no consistency as to which system was being invoked during land dispute arbitrations. Unlike in common law systems, Rwanda's constitution allowed for a parallel legal system, thus judges could arbitrarily apply customary land laws in certain cases but not in others (Crook 2006). This became a tool for certain sections of the Hutu population to further displace Tutsis from their land and add to mounting hostilities.

Due to these variable land tenure policies, coupled with sporadic violent attacks on Tutsi populations, it is estimated that approximately 600,000 Rwandansmostly Tutsi, but some Hutu-fled the country in the period between 1959 and 1990. It was this population of Tutsi refugees that formed the Rwandan Patriotic Front (RPF), which invaded Rwanda in 1990, thus commencing the civil war that would continue through 1994 after the conclusion of the genocide and the seizure of Kigali by the RPF.

\section{Côte d'Ivoire}

The build up to violence in Côte d'Ivoire is similar to the Rwandan case in that competition over land contributed to the violence (Chauveau and Richards 2008). However, the competition was not between two local ethnicities as it was in Rwanda, but rather between native Ivoirians and immigrants from surrounding countries, particularly Burkina Faso 
and Mali. The Ivoirian case highlights the problems that can arise when local or customary institutions differ from national governments on issues of land tenancy. This case also illustrates how "exogenous demographic changes, especially in the absence of economic development, will increase the scarcity and value of land," and how this can challenge the customary authorities that "previously had unquestioned authority over land allocation and dispute resolution" (World Bank 2003, 24).

The French introduced coffee and cocoa production to Côte d'Ivoire in the early 2oth century. The southern, fertile, forested zone was the perfect climate for these crops and both French and Ivoirian farms began to expand there. To help with the demand for labor, the French welcomed immigrants from other countries into Côte d'Ivoire. From the time of independence and the French departure in 1960 through the 1980 s, the price of both cocoa and coffee increased significantly. This increase continued to entice many northern Ivoirians as well as additional immigrants from neighboring countries to flock to the forest zone of the country, clear land, and plant additional crops for export. During this period, President Houphouet-Boigny continued the French policies that supported high immigration.

In the years spanning from independence to the outbreak of civil war, formal land tenure policies were not well implemented in rural areas. In 1963, the National Assembly proposed a national land code; however, it was never approved by the president and was never administered (Rasaam 1990). In the 1990s, several decrees and laws were passed based on the colonial laws. Land registration and transfer procedures became routine in the urban areas, but they did not take effect in rural areas (1990). Rural areas stayed largely untouched by codified land tenure because there was no obvious threat to production that required their application. From the government's perspective, the customary systems were working, so there was no incentive to enforce a formal system (1990).

In lieu of a formal system, the southern zones operated primarily under the "tutorat" system. In this patron-client relationship, customary landowners or "first comers," i.e., those who initially cleared the forested land for cultivation, could concede long-term land administration rights to migrant farmers, both from other countries and from the northern savannah region. This system fit into the culture's moral principle that all people have a "right of access to the means of subsistence for himself and his family" (Chauveau and Colin 2010, 87). In the tutorat, the migrant owed his "tuteur" gratitude, usually in the form of money, for the right to use the land. Such agreements were transferable between generations. When the original tuteur died, the next of kin assumed the tuteur role. Similarly, when the migrant died, his administration rights to the land passed to the heir. As commodity prices increased in the 1960 s, the native Ivoirian community began to notice that the migrant farmers on their land were generating large monetary surpluses. As a result, the tuteurs began to demand higher land fees or gratitude payment (2010). Under President Houphouet-Boigny, a supporter of the northern and immigrant populations, the government formally forbade tuteurs from demanding land fees from the migrant farmers; however, in practice this meant that the tuteurs increased their initial gift fees that granted migrant farms initial access to their land (2010).

In the mid-1980s, tensions began to rise, partially due to the administration of the tutorat system. Beginning in 1987 and continuing through the 1990 , the prices of cocoa and coffee began to fall, resulting in a greater push into the forested region to clear additional land in order to increase production to recoup lost profits (Kouadio 2009). The economic downturn also caused many 
urban dwellers to return to their family's rural land in hope of finding work only to find large immigrant populations working there (Chauveau and Colin 2010).

This lack of work created tensions within families whose youth wanted to end established tutorat agreements and evict the migrants.

Matters worsened in 1993 when Houphouet-Boigny died and Henry Bédié assumed the presidency. Unlike his processor, Bédié did not support the immigrant populations and instead advocated for Ivoirité, a concept promoting stronger cultural identity that was later adopted as a term to mean ethnic or native Ivoirian, and which favored ethnic Ivoirians over foreigners. In 1994, immigrants lost their voting rights, and in 1998, anti-immigrant land tenure laws were passed that forbade immigrants from owning land. In 1999, many immigrant farmers were forced off of their lands, having a considerable effect on the population, which by 1998 was 26 percent foreign-born (Kouadio 2009). All together, the social and political environment created by the failing economy, harsh immigration laws, and increasing populations of landless young people, both immigrant and Ivoirian, was ripe for conflict. The catalyst came just prior to the 2000 elections when interim president Robert Guéi succeeded in getting referendum passed declaring that both parents of presidential candidates must be Ivoirian-born, thus preventing Alassane Ouattara, the pro-north leading candidate and immigrant supporter, from competing. Laurent Gbagbo won the 2000 election, and in 2002, the civil war began as rebel groups from the ostracized north and disgruntled immigrant populations from the south attacked.

\section{Analysis of Post-Conflict Land Tenure Policies}

Post-conflict reconstruction is a massive challenge, and, unlike other areas related to international development, the body of knowledge, established laws, and practices for how to rebuild governments and institutions in post-conflict environments is still in the early years of development (Brinkerhoff 2005). There are, however, several themes that are evident in the existing body of post-conflict literature. First, participants in reconstruction, both internal and external, must develop a deep, common understanding of the historical context in which the conflict occurred and the root causes of the conflict (The African Capacity Building Foundation 2004). They must "understand the varying histories and nature of the 'failure' process in order to calibrate informed intervention and measures to facilitate the transition from war to sustainable peace" $(2004,6)$. Next, any strategies or timetables developed by the international donor community need to be adjusted to fit local circumstances (Brinkerhoff 2005). Also, any post-conflict policy reforms must begin with an open and broad-based dialogue that engages all levels of society (World Bank 2003). Pilot programs should be implemented and carefully evaluated. Also, information should be shared between countries experiencing similar changes (2003). Even if pilot programs are successful, consideration must be given to whether the country has the trained personnel ready to implement the changes on a national scale. The final common note across post-conflict studies is that the reconstruction process can take decades, and the risk of conflict will remain a threat (The African Capacity Building Foundation 2004). As researchers from both the World Bank and FAO summarize:

Issues of land policy are generally complex, countryspecific, of a long-term nature and often controversial politically. This demands particular attention to the sequencing of reforms as well as their political economy. Even if land-related interventions will make society 
as a whole better off, they may be challenged by vested interests that derive considerable benefits from the status quo. Effective policy reform will be made more feasible by open and broadly based policy dialogue, carefully chosen and evaluated pilot projects and sharing of experience across countries (Deininger et al. 2003).

In the cases of Rwanda and Côte d'Ivoire, we find that Rwanda has been relatively successful in meeting the majority of these prescriptions, albeit with a slow start. In contrast, Côte d'Ivoire continues to struggle, but perhaps change will begin to emerge with the passage of two recent laws.

\section{Rwanda}

More than a decade after the conflict, the National Unity and Reconciliation Committee, established to help facilitate peace, found that "land disputes are the greatest factor hindering sustainable peace" (Huggins et al. 2012; Republic of Rwanda 2002a). Knowing this, the Rwandan government has pursued many land-related initiatives. In 1996, less than 2 years after the conclusion of the civil war, the Ministry of Agriculture and Livestock began to advocate for new land laws. This push led to the 1997 study on land reform funded by the FAO, which concluded that family lot sizes needed to become indivisible in order to ensure the plot sizes would not be too small to be usable. In 1998, the Ministry of Agriculture and Livestock formed a commission with the aim to start developing parameters for a new land law. The commission worked with local administrators, farmers' representatives, and NGOs throughout the country. The information gathered from the commission contributed to the initial development of land policies, which began in 2000 under the leadership of the Ministry of Lands, Environment, Forestry, Water and Natural Resources (MINITERE). MINITERE continued to work with stakeholders at the district level and circulated the draft policies to the Rural Development Institute, Oxfam, and the Rwandan Initiative for Sustainable Development (RISD). Other landrelated policies were adopted during this period, including the 1999 Inheritance Law that banned gender discrimination in land inheritance and the 2001 Poverty Reduction Strategy Paper, which singled out land as being "the most productive asset owned by Rwandese households" and stated that the security and resolution of land disputes should be of primary importance to the government (Republic of Rwanda 2002b).

Finally, the Rwandan government passed the "Organic Law Determining the Use and Management of Land of 2005," which achieved several important objectives. First, it establishes a single, codified land tenure system that ends the dualism created by the parallel customary and formal land systems of the pre-conflict environment (Ali et al. 2011). Second, the law recognizes land acquired through customary systems, but requires all land plots to be registered and institutes a minimum plot size of 1 hectare (ha). Third, the law declares that all land is owned by the state, which then leases it to holders via 99-year leases that are both transferable and renewable. Finally, the law establishes the National Land Center and District Land Bureaus to administer the land policies. The idea behind these policies is that they will make land more productive and reduce the number of land-related disputes.

This law is laudable for several reasons. First, the government was careful to facilitate broad-based discussions about the land policies in the years leading up to the passage of the law. In addition, since the implementation of the law, the National Land Center has initiated a series of land tenure regularization 
pilot programs in an effort to determine the best methods for registering plots and defining land boundaries (Ali et al. 2011). These pilots have been successful on the micro level, which gives hope for their implementation on a national scale. In addition, through the creation of the District Land Bureaus, the government is making an effort to keep the land registration process decentralized.

Despite the benefits of the new land law, it has several shortcomings that must be addressed if the new land policies are to succeed long-term. The minimum 1 ha size requirement for plot registration has been criticized for being larger than the 0.75 ha size that is recognized as being viable (Pottier 2002). As the most densely populated country in Africa, this 0.25 ha difference means land will be available for some and not for others, especially since, as of 2005, the average land holding per person in Rwanda was $0.71 \mathrm{ha}$. This issue of plot size is related to the other main criticism of the law: it does not adequately address what will happen to those who will be rendered landless by its implementation. Land holders with plots smaller than 1 ha who cannot afford to purchase a 1 ha plot will be forced to lose their original plot so that it can be consolidated with other small plots. Under the law, this group of people will be compensated; however, the method has yet to be determined. Another landless population left unaddressed by the law is returning refugees. Per the Arusha Accords, signed in 1993 as a means to facilitate peace and end civil war, anyone who remained out of the country for 10 years or longer is not eligible to stake a claim over land (2002). The law does not offer other employment opportunities or training programs for those made landless by the law. Without an alternative readily available, the risk of discontent increases (Gayoso 2013).

Perhaps the most important concern regarding the post-conflict land tenure policies is whether they simply replace the pre-conflict, racially based inequality with a socio-economic inequality, i.e., only individuals with enough money to own 1 ha of land are given access to it. Could this economic inequality actually result in more insecurity (Peters 2009)? Rwanda's 2011 Gini coefficient, a measure of income distribution equality where zero represents perfect distribution equality and 100 represents perfect inequality, was 50.8 (World Bank Development Indicators 2013), placing it in the top third of the most unequal societies in the world. Rwanda will need to monitor whether the new land law exacerbates resource inequality and exclusion, as those were the same underlying issues that contributed to the 1994 genocide (Pottier 2002).

\section{Côte d'Ivoire}

Unlike the Rwandan government that has made continuous efforts with the help of internal NGOs and the international community to reform its land tenure policies, the Ivoirian government has only started in recent months to take steps to reform its land tenure policies. Yet, during the interim period between the conclusion of its first civil war in 2007 and the outbreak of the second in 2011, no progress was made, and the country relied on its flawed 1998 land law as the sole means of resolving land disputes. In addition to the fact that national laws continued to maintain that Ivoirians could hold title to their lands while non-Ivoirians are only entitled to long-term leases (McCallin and Montemurro 2009), the main shortcoming of the law was its lack of enforceability and administration, primarily due to severe shortages in state capacity. Furthermore, given that the law was written before the civil war, it included no prescriptions for how to address land tenure issues now that there are hundreds of thousands of internally displaced persons (IDPs) in the country.

$$
\text { Another issue is establishing }
$$
ownership or title to the land. As stated earlier, one of the main elements to 
ensure successful land tenure is for land boundaries to be clear. In order to determine land boundaries, the owner first claims the land, then the state surveys it, and then the title or lease is granted. The law made this particularly cumbersome because it requires that any formal land ownership requests be made at the site where the plot land is located (2009). This requirement was particularly problematic for internally displaced persons who were unable to make the physical journey to their land. Land surveying was, and remains, equally challenging given that as of 2008 the country only had 23 land surveyors to cover over 20 million ha of land (2009).

Enforcement of the 1998 land law was also inadequate in the post-war environment as the country's justice system was, and continues to be, not fully functional. Instead of settling land disputes, courts often sent plaintiffs back to customary institutions, such as the tutorat, when the courts were unable to establish relevant facts or validate informal written notes that attest to customary land exchanges (2009). These referrals created difficulties in the post-conflict environment, as many customary chiefs were IDPs themselves and thus were not able to settle land disputes when they are brought forth (2009).

Another challenge with the 1998 land law was its requirement that any lands granted under customary systems be formally registered within ten years. Any land not formally registered would revert to the state and be considered "ownerless" (Stamm 2000). The law did not provide any information about what farmers were supposed to do should their land be declared ownerless. Furthermore, since the law was drafted prior to the war, it did not include any mention of compensation for the IDPs who were forced to abandon their land and who subsequently lost their rights to it (McCallin and Montemurro 2009).

Finally, perhaps the greatest concern related to the 1998 land law was that most Ivoirians had not been educated about it. Prior to the civil war, some small-scale pilot land registration programs were administered (Stamm 2000), but few are aware of the law's procedures or their rights under it. If citizens are not informed of the law, how could it ever be successful?

Fortunately, in August 2013, the Ivoirian National Assembly passed new laws related to nationality requirements and land tenure. The two laws passed regarding nationality formally implement the objectives of the Marcoussis Accords that have existed since 2003 but were never implemented. These new laws allow foreigners to become Ivoirian citizens if married to an Ivoirian citizen and also allow for foreign-born residents who have lived in the country prior to independence to become citizens (Aboa 2013). In addition, anyone born in the country between 1960 and 1973 is declared "Ivoirian," even if their parents are foreign-born, and have two years to claim their citizenship. The land tenure reforms under the new laws include an extension of the ten-year registration requirement under the 1998 law, noted above, and give non-Ivoirians the ability to own land (2013). The United Nations' independent expert on Côte d'Ivoire, Doudou Diène, has indicated that these issues have been at the core of Côte d'Ivoire's conflicts, so together, these laws should ease some of the challenges presented by the 1998 law and hopefully reduce the likelihood of future conflict. Of course, the international community and Ivoirians alike will need to see how these laws are implemented over the coming months and years in order to determine their true effectiveness.

\section{Recommendations}

While conflicts vary greatly from country to country and require custommade responses, every response should begin with an understanding of the conflict's root causes as it will "help to inform reconstruction and capacity-de- 
velopment interventions that are likely to serve as credible and sustainable conflict mitigation measures for societal healing and capacity development" (The African Capacity Building Foundation 2004, 13). The role of the international community and NGOs will vary depending upon the nature of conflict, but especially in cases where land tenure is a root cause, these players have key roles to play in helping to implement land tenure policy reforms. Immediately following conflict, multilateral organizations such as the UN and the World Bank could provide specialists in land tenure and land administration to help investigate key issues and document the scope and severity of existing land tenure problems. As seen in Rwanda, NGOs, such as RISD, were instrumental in working with locals to get participation in the land tenure reform process (Musahara and Huggins, 2005). These organizations could also be a powerful voice in pushing land tenure problems onto the post-conflict reconstruction agenda. Since land tenure issues are often closely interwoven with other complex issues, such as ethnic tension in Rwanda and immigration in Côte d'Ivoire, people who set the priorities in the reconstruction and recovery process may not realize land tenure as an underlying issue, which, if not addressed, could lead to continued conflict. Indeed, even with the success seen in Rwanda, land disputes are still noted as being "the greatest factor hindering sustainable peace" (Huggins et al. 2012; Republic of Rwanda 2002a).

In post-conflict situations, the international community can also play a pivotal role in the capacity building of civil servants, as no reform can be effective if trained staffs are not available to implement solutions. Japan's post-World War II land reform experience demonstrates the importance of having trained staff available. Indeed, it is noted that one of the main reasons that Japan's land reforms were a success is due to the presence of land specialists and other well-educated staff that were ready to engage in the work (Kawagoe 1999). For countries like Rwanda that lack a core of trained staff, the international community can help fill the gap by providing trained technicians who can provide onthe-job training to locals so that they can assume complete responsibility in the long-term. In Côte d'Ivoire, the international community can start civil servant capacity-building programs now so that staffs are prepared to implement the new policies.

The lessons learned from

Rwanda and Côte d'Ivoire should also be documented so that other countries can learn and benefit from their experiences. In February 2013, Kenyan elections were marred by violence associated with land issues and ethnic tension (Gettleman 2013). If these issues compound over time, as they did in both Rwanda and Côte d'Ivoire, similar violence could erupt. The international community should seize the opportunity to promote land tenure reform now to deter conflict in future years.

\section{References}

Aboa, Ange. 2013. "Ivory Coast Lawmakers Pass Critical Land, Nationality Laws." Reuters, August 23rd. Accessed December 18, 2013. http://www.reuters.com/ article/2013/o8/23/us-ivorycoast-laws-idUSBRE97MoY120130823

Aka, Bédia. 2007. "Gender, Land Access and Rural Poverty in Côte d'Ivoire." International Journal of Applied Economics and Quantitative Studies Volume 4, no.1:21-34. 
Ali, Daniel A., Klaus Deininger, and Markus Goldstein. 2011. "Environmental and Gender Impacts of Land Tenure Regularization in Africa: Pilot evidence from Rwanda." Policy Research Working Papers 5765:1-31. Accessed February 10, 2013. doi 10.1596/ 1813-9450-5765.

Antonio Gayoso, interview by Katherine Cronin, April 2013.

Auty, Richard M. 2010. "Elites, Rent-Cycliny and Development: Adjustment to Land Scarcity in Mauritius, Kenya and Côte D'Ivoire.” Development Policy Review vol. 28 , no. 4:411-433.

Brinkerhoff, Derrick W. 2005. "Rebuilding Governance in Failed States and Post-Conflict Societies: Core Concepts and Cross-Cutting Themes.” Public Administration and Development vol. 25, no.1:3-14.

Brinkerhoff, Derick W., and Jennifer M. Brinkerhoff. 2002. "Governance Reforms and Failed States: Challenges and Implications." International Review of Administrative Sciences vol. 68, no.4:511-531.

Chavuveau, Jean-Pierre, and Jean-Philippe Colin. 2010. "Customary Transfers and Land Sales in Côte D’Ivoire: Revisiting the Embeddedness Issue.” Africa: The Journal of the International Africa Institute, vol. 80, no. 1:81-103.

Crook, Jamie. 2006. "Promoting Peace and Economic Security in Rwanda through Fair and Equitable Land Rights." California Law Review vol. 94, no. 5:1487-1536.

Deininger, K., G. Feder,G.Gorillo de Anda, and P. Munro-Faure. "Land Policy to Facilitate Growth and Poverty Reduction." Journal of Land Reform, Land Settlement and Cooperatives 3:5-18.

FAO (Food and Agriculture Organization). 2005. "Access to Rural Land and Land Administration after Violent Conflicts.” In FAO Land Tenure Studies No. 8. Rome: FAO.

Gettleman, Jeffrey. 2013. "Neighbors Kill Neighbors as Kenyan Votes Stirs Old Feuds." New York Times, February 21st . Accessed April 15, 2013. http://www.nytimes.com/2013/02/22/world/africa/neighbors-kill-neighbors-in-kenya-aselection-tensions-stir-age-old-grievances.html

Hendrix, Steven. 1997. "Pride of Ownership: Land Tenure and Conflict Resolution.” Harvard International Review: 40-43.

Huggins, Chris, Herman Musahara, Prisca Mbura Kamungi, Johnstone Summit Oketch and Koen Vlassenroot. 2005. "Conflict in the Great Lakes Region How is it Linked with Land and Migration?" Natural Resource Perspectives no.96:1-4.

IFAD (International Fund for Agricultural Development). 2012. "Land Tenure Security and Poverty Reduction.” Accessed February 10, 2013. http://www.ifad.org/pub/factsheet/land/e.pdf

Kawagoe, Toshihiko. 1999. "Agricultural Land Reform in Postwar Japan: Experiences and Issues.” World Bank Policy Research Working Paper 2111:1-43. Accessed February 20, 2013. doi:10.1596/1813-9450-2111

Kouadio, Bertin K. 2009. "From Stability to Insurgency: The Root and Proximate Causes of the September 2002 Civil war in Côte D’Ivoire.” Ph.D. diss., Florida International University.

McCallin, Barbara, and Marzia Montemurro. 2009. "Whose Land is This? Land Disputes and Forced Displacements in the Western Forest Area of Côte d'Ivoire." Abidjan: Norwegian Refugee Council.

Musahara, Herman, and Chris Huggins. 2005. "Land Reform, land scarcity and postconflict reconstruction: A case study of Rwanda." In From the Ground Up: 
Land Rights, Conflict and Peace in Sub-Saharan Africa, edited by Chris Huggins and Jenny Clover, 269-346. Pretoria: Institute for Security Studies.

Peters, Pauline P. 2009. "Challenges in Land Tenure and Land Reform in Africa: Anthropological Contributions.” World Development vol. 37, Issue 8:1317-1325.

Pottier, James. 2002. "Land Reform for Peace? Rwanda's 2005 Land Law in Context." Journal of Agrarian Change vol. 6, no.4: 509-537.

Rassam, Amal. 1990. "Land Tenure in the Ivory Coast: A developing problem and a problem for development." Madison: The Land Tenure Center- University of Wisconsin.

Republic of Rwanda. 2002a. “A Profile of Poverty in Rwanda.” Kigali: Ministry of Finance and Economic Planning.

. 2002b. "Poverty Reduction Strategy Paper." Kigali: Ministry of Finance and Economic Planning.

The African Capacity Building Foundation. 2004. Reconstruction and Capacity Building in Post-Conflict Countries in Africa: A Summary of Lessons of Experience From Mozambique, Rwanda, Sierra Leone \& Uganda."

The CIA World Factbook. 2013. "Rwanda.” Accessed February 10, 2013. https://www. cia.gov/library/publications/the-world-factbook/geos/rw.html

Stamm, Volker. 2000. The Rural Land Plan: An Innovative Approach from Côte d'Ivoire. London: International Institute for Environment and Development.

United Nations Human Rights. 2013. "Côte D'Ivoire: 'Adoption of laws on nationality and land tenure, major step towards reconciliation,' says UN expert.” Accessed November 20, 2013. http://www.ohchr.org/EN/NewsEvents/Pages/DisplayNews.aspx?NewsID=13669andLangID $=\mathrm{E}$

The World Bank. 2003. "Land Policies for Growth and Poverty Reduction.” World

Bank Policy Research Report. Accessed February 15, 2013. http://info.worldbank.org/etools/docs/library/34919/landpoliciesexecsummary.pdf

. 2012 "World Development Indicators." Accessed February 15, 2013. http://databank.worldbank.org

Katherine M. Cronin is a second year Master of Public Administration candidate at the George Washington University, concentrating in international development management. In addition to her graduate studies, Katherine works full-time as a Senior Advisor at the Consumer Financial Protection Bureau (CFPB) where she has been for the past three years. Prior to the CFPB, Katherine worked as a management analyst at the National Science Foundation and served as a Peace Corps volunteer in Benin, West Africa. She graduated magna cum laude with a BA in political science from Columbia University. Outside of work and school, Katherine is a certified yoga instructor and can be found teaching and practicing yoga in studios around Washington, DC.

The author would like to thank Odia Cisse, Brandon Kruse, and Professor John Forrer for their feedback during the editing process. She would also like to thank Professor Joan Dudik-Gayoso for encouraging her to submit to Policy Perspectives. Finally, the author is grateful for her family and friends who have been both supportive and patient as she pursues her academic and professional ambitions. 